\title{
Achieving Environmentally Sustainable Livestock Production
}

\author{
Ilkka Leinonen \\ Department of Rural Economy, Environment and Society, Scotland's Rural College (SRUC), Peter Wilson \\ Building, Kings Buildings, West Mains Road, Edinburgh EH9 3JG, UK; ilkka.leinonen@sruc.ac.uk; \\ Tel.: +44-131-5354044
}

Received: 2 January 2019; Accepted: 4 January 2019; Published: 7 January 2019

Livestock production is a major global source of greenhouse gas emissions [1] and high density of livestock in certain areas can also create local environmental issues such as harmful levels of ammonia emissions and regional nutrient imbalances [2,3]. However, future improvements in the global livestock sector can also be seen as a potential opportunity for delivering a significant share of the necessary mitigation of global warming and other environmental problems [1]. In fact, it has been demonstrated that significant reductions in various environmental impacts and especially in the emissions intensities (i.e., the amount of emissions per unit of product) have been already achieved in livestock production during the past decades, for example through breeding, optimized feeding, improved health status of animals, and improved manure management [4-6].

This Special Issue presents results from studies on different measures aiming to improve the environmental sustainability of livestock production and to mitigate environmental impacts, including emissions of greenhouse gases (carbon dioxide, methane, and nitrous oxide), nitrogen and phosphorus excretion, ammonia emissions, land use and use of energy and other resources. Globally the most important livestock species (beef and dairy cattle, pigs, broiler chicken and laying hens) are covered in the papers published here. The mitigation methods assessed in the papers include general system changes (together with novel approaches to comparison of alternative production systems), changes in feeding, improvement of animal health, and new technologies of manure management.

The scope of the papers included in this Special Issue range from farm level mitigation methods to national level system changes. One of the national-level articles, written by Pelletier et al. [7], presents an overview of the sustainability of the Canadian egg production industry. The authors provide an interdisciplinary perspective to this industry, considering its past, present, and potential futures. Their analysis covers environmental, institutional, and socio-economic sustainability with a special emphasis on animal welfare. The analysis identifies major challenges for sustainable egg industry, including shifting consumer and other stakeholder preferences and expectations, and conflicts between the expectations and scientific evidence. A thorough discussion is provided on possible strategies to resolve these issues.

The methodology of Life Cycle Assessment (LCA) is becoming a standard in evaluating the environmental sustainability of livestock systems, but LCA also has applications in the areas of social (S-LCA) and economic (life cycle costing) sustainability assessment. In contrast to relatively well established methods of environmental Life Cycle Assessment, the methods of S-LCA are still under development. In his second paper in this Special Issue, Nathan Pelletier [8] develops a suite of context-appropriate indicators and metrics to characterize the social risks and benefits specific to activities at Canadian egg production facilities and then applies those indicators to perform a detailed assessment of the "gate-to-gate" social risks and benefits of Canadian egg production facilities. The analysis presented here provides a starting point for expanding the methodology to cover the whole production chain and thus enable a full social life cycle assessment. 
In their paper, Cai et al. [9] carry out a national level study on a reduction of the emission intensities (per unit of the monetary value of output) of non- $\mathrm{CO}_{2}$ greenhouse gases arising from the livestock sector in China, through an analysis of the contribution of each province to the overall national emissions. They especially concentrate on the role of three "driving factors," i.e., environmental efficiency, productive efficiency and economic share, in determining the national greenhouse gas emission intensity. Their findings suggest that the productive efficiency (i.e., the input of production factors per unit of output value) is the main contributor to the changes in the emission intensities, and improvement in this factor has resulted in a considerable reduction of livestock sector emission intensity at the national level during the period of 1997-2016.

The effect of system changes on the productivity of cattle production in the Amazon biome was evaluated by zu Ermgassen et al. [10]. The key question in their study is how to handle the increasing agricultural production in Brazil (e.g., currently the World's second largest cattle herd) and at the same time protect remaining natural vegetation. The authors found that currently the cattle productivity in the Amazon biome is very low, and intensification of the cattle production systems would be the key factor in achieving higher environmental sustainability. In their paper, they present results from six initiatives in the Brazilian Amazon, which have successfully improved the productivity in beef and dairy systems.

Brazilian livestock production is also considered in the paper by Santos and Costa [11]. They tested the hypothesis according to which large slaughterhouses are potential leverage points for promoting sustainable intensification in the beef supply chain in Amazonia and the Cerrado, due to their interactions with ranchers, their location at the agricultural frontier, and their ability to control access to the market. The authors' conclusion was that although cattle-ranching intensification (with positive effect on environmental indicators) has occurred in the Cerrado, this development is independent of the presence of large slaughterhouses. Instead, the authors suggest that conservation measures such as a strong monitoring systems and more restrictive environmental policies would be the key promotes of environmental sustainability, especially at the Amazonia region.

In their article, Nieto et al. [12] assess the on-farm greenhouse gas emissions from beef production in semi-arid rangelands in Argentina and apply statistical analyses to identify the relationship between emissions and current farm management practices. Their results highlight the importance of efficient production in achieving environmental sustainability of livestock production. Their findings indicate that the emissions per product were low on farms that had improved livestock care management, applied rotational grazing, and had access to technical advice. The authors suggest that "implementation of realistic, relatively easy-to-adopt farming management practices has considerable potential for mitigating the GHG emissions in the semi-arid rangelands of central Argentina."

Livestock production in Europe has been considered to be highly intensive, and thus relatively efficient. However, many low-intensity systems exist as well, especially in organic production. In the study by Rudolph et al. [13] a system comparison using environmental LCA was carried for three European organic pig production systems, namely indoor, partly outdoor, and outdoor. The authors found a great between-farm variation in three environmental indicators: global warming, acidification and eutrophication potentials. The differences between the farms were mainly affected by feed production and to some extent also by housing. There were no between-system differences in global warming potential, but acidification potential was highest in the indoor system (as a result of ammonia emissions) and the eutrophication potential highest in the outdoor system (as a result of nutrient leaching). The authors conclude that the occurrence of organic farms with low environmental impacts indicates that it is possible to manage organic pig production in an environmentally friendly way.

Using agricultural by-products (that are not suitable for human consumption) as part of livestock feed has been considered to be one method to improve the environmental sustainability of livestock production. In their study, Leinonen et al. [14] assess the environmental consequences of using distillery by-products as a protein source for beef cattle in Scotland. Their study highlights the complexity of livestock feed production chains. This was demonstrated by the alternative uses of agricultural 
by-products (in this case either as a livestock feed or as a source of renewable energy), and the environmental impacts arising from those options were analyzed through the system expansion-based LCA approach.

Another option to reduce the environmental impacts through livestock feeding is to apply resource efficient feed formulation. Ullrich et al. [15] evaluated the potential of reducing the crude protein level of the broiler diet by using supplementation of single amino acids to achieve an optimum amino acid balance of the feed. Their experimental results confirm some earlier modelling studies [16] according to which a balanced diet with lowered crude protein concentration can reduce the amount of nitrogen excreted, which has multiple environmental benefits. It is also demonstrated that such an improvement can be achieved without compromising animal performance.

The link between livestock feeding and climate change is not only a one direction process. The feed formulation in the future may also be affected by changes in the availability and quality of certain feed ingredients, and such changes can be induced by global warming and increased atmospheric $\mathrm{CO}_{2}$ concentration. Saxe et al. [17] applied a consequential life cycle assessment to quantify the environmental impacts and socio-economic effects that altered crop yields and chemical composition of the crops at elevated $\mathrm{CO}_{2}$ levels in the future can have on pig feed formulation. They predict that the elevated $\mathrm{CO}_{2}$ reduces the land use demand for pig feed production, but at the same time increases the demand for protein crops (soya), due to reduced protein concentration of feed crops. This will have considerable environmental and economic consequences.

In cattle production, methane from enteric fermentation and manure management is generally considered to be the most significant greenhouse gas. However, nitrous oxide emissions related to ruminant feeding have also their own role in the total emissions from this livestock sector. In their article, Gerlach et al. [18] present a new method for determining the concentrations of $\mathrm{CO}_{2}, \mathrm{CH}_{4}$, and $\mathrm{N}_{2} \mathrm{O}$ in the ruminal gas phase of steers after ingestion of different forage types. Depending on the diet, high concentration of $\mathrm{N}_{2} \mathrm{O}$ were found in the rumen, indicating that that fermented forages rich in nitrogen can be a significant source of greenhouse gases.

Improving the health status of animals is one option to maintain high production efficiency of livestock and in this way keep the emission intensity at the minimal level. In their paper, MacLeod et al. [19] apply the FAO livestock model GLEAM to quantify the greenhouse gas emissions from East African cattle production systems and the effects of an endemic disease trypanosomiasis on the emissions. The authors found that removing that disease could lead to a reduction in the emissions intensity per unit of protein produced, as a result of increases in milk yields and higher cow fertility rates. Another major issue related to animal health is antibiotic resistance, and this has also links to the environmental impacts of livestock production. In their comprehensive review, Schmithausen et al. [20] highlight knowledge gaps and various factors that contribute to the transmission of antibiotic-resistant bacteria between animals, humans, and the environment in pig production, following a holistic "One Health" approach.

Although most papers in this special issue focus on livestock husbandry and its effect on animal performance when considering possible methods for reducing the environmental impacts of livestock system (and their potential effects on human health), different manure management options can potentially also control such impacts. Reduction of ammonia emission through improved manure management has direct consequences on human and animal health, and it also affects numerous environmental issues such as eutrophication, acidification, and global warming. In this Special Issue, novel technologies of manure management are considered in the paper by Baldi et al. [21], who show results of a comparison of ammonia stripping methods aiming to reduce the emissions arising from digestate derived from anaerobic digestion of livestock manure and corn silage.

In summary, this Special Issue demonstrates a range of opportunities that would help to reduce the environmental impacts of global livestock production. Most of the papers identify the efficiency of the production as a key factor to affect the emission intensity of the livestock products. To assess the possible improvements in efficiency, holistic approaches such as Live Cycle Assessment would 
be necessarily needed, and further methodological development in this area is still required [22]. This would be especially a challenge when linking together the three pillars of sustainability (environmental, social, and economic) in sustainability assessments of livestock production.

Funding: This research was partly funded by the Scottish Government Rural Affairs and the Environment Portfolio Strategic Research Programme 2016-2021, WP 1.4 'Integrated and Sustainable Management of Natural Assets' and 2.4 'Rural Industries'.

Conflicts of Interest: The author declares no conflict of interest.

\section{References}

1. Gerber, P.J.; Steinfeld, H.; Henderson, B.; Mottet, A.; Opio, C.; Dijkman, J.; Falcucci, A.; Tempio, G. Tackling Climate Change through Livestock. A Global Assessment of Emissions and Mitigation Opportunities; Food and Agriculture Organization of the United Nations (FAO): Rome, Italy, 2013; ISBN 978-92-5-107921-8.

2. Vitousek, P.M.; Naylor, R.; Crews, T.; David, M.B.; Drinkwater, L.E.; Holland, E.; Johnes, P.J.; Katzenberger, J.; Martinelli, L.A.; Matson, P.A.; et al. Nutrient imbalances in agricultural development. Science 2009, 324, 1519-1520. [CrossRef]

3. Leinonen, I.; Eory, V.; MacLeod, M. Applying a process-based livestock model to predict spatial variation in agricultural nutrient flows in Scotland. J. Clean. Prod. 2018, 209, 180-189. [CrossRef]

4. Pelletier, N.; Ibarburu, M.; Xin, H. Comparison of the environmental footprint of the egg industry in the United States in 1960 and 2010. Poult. Sci. 2014, 93, 241-255. [CrossRef] [PubMed]

5. Tallentire, C.W.; Leinonen, I.; Kyriazakis, I. Breeding for efficiency in the broiler chicken. A review. Agron. Sustain. Dev. 2016, 36, 66. [CrossRef]

6. Tallentire, C.W.; Leinonen, I.; Kyriazakis, I. Artificial selection for improved energy efficiency is reaching its limits in broiler chickens. Sci. Rep. 2018, 8, 116. [CrossRef] [PubMed]

7. Pelletier, N.; Doyon, M.; Muirhead, B.; Widowski, T.; Nurse-Gupta, J.; Hunniford, M. Sustainability in the Canadian Egg Industry-Learning from the Past, Navigating the Present, Planning for the Future. Sustainability 2018, 10, 3524. [CrossRef]

8. Pelletier, N. Social Sustainability Assessment of Canadian Egg Production Facilities: Methods, Analysis, and Recommendations. Sustainability 2018, 10, 1601. [CrossRef]

9. Cai, T.; Yang, D.; Zhang, X.; Xia, F.; Wu, R. Study on the Vertical Linkage of Greenhouse Gas Emission Intensity Change of the Animal Husbandry Sector between China and Its Provinces. Sustainability 2018, 10, 2492. [CrossRef]

10. Zu Ermgassen, E.; Alcântara, M.; Balmford, A.; Barioni, L.; Neto, F.; Bettarello, M.; Brito, G.; Carrero, G.; Florence, E.; Garcia, E.; et al. Results from On-The-Ground Efforts to Promote Sustainable Cattle Ranching in the Brazilian Amazon. Sustainability 2018, 10, 1301. [CrossRef]

11. Santos, A.; Costa, M. Do Large Slaughterhouses Promote Sustainable Intensification of Cattle Ranching in Amazonia and the Cerrado? Sustainability 2018, 10, 3266. [CrossRef]

12. Nieto, M.; Barrantes, O.; Privitello, L.; Reiné, R. Greenhouse Gas Emissions from Beef Grazing Systems in Semi-Arid Rangelands of Central Argentina. Sustainability 2018, 10, 4228. [CrossRef]

13. Rudolph, G.; Hörtenhuber, S.; Bochicchio, D.; Butler, G.; Brandhofer, R.; Dippel, S.; Dourmad, J.; Edwards, S.; Früh, B.; Meier, M.; et al. Effect of Three Husbandry Systems on Environmental Impact of Organic Pigs. Sustainability 2018, 10, 3796. [CrossRef]

14. Leinonen, I.; MacLeod, M.; Bell, J. Effects of Alternative Uses of Distillery By-Products on the Greenhouse Gas Emissions of Scottish Malt Whisky Production: A System Expansion Approach. Sustainability 2018, 10, 1473. [CrossRef]

15. Ullrich, C.; Langeheine, M.; Brehm, R.; Taube, V.; Siebert, D.; Visscher, C. Influence of Reduced Protein Content in Complete Diets with a Consistent Arginine-Lysine Ratio on Performance and Nitrogen Excretion in Broilers. Sustainability 2018, 10, 3827. [CrossRef]

16. Leinonen, I.; Williams, A.G. Effects of dietary protease on nitrogen emissions from broiler production: A holistic comparison using Life Cycle Assessment. J. Sci. Food Agric. 2015, 95, 3041-3046. [CrossRef] 
17. Saxe, H.; Hamelin, L.; Hinrichsen, T.; Wenzel, H. Production of Pig Feed under Future Atmospheric CO2 Concentrations: Changes in Crop Content and Chemical Composition, Land Use, Environmental Impact, and Socio-Economic Consequences. Sustainability 2018, 10, 3184. [CrossRef]

18. Gerlach, K.; Schmithausen, A.; Sommer, A.; Trimborn, M.; Büscher, W.; Südekum, K. Cattle Diets Strongly Affect Nitrous Oxide in the Rumen. Sustainability 2018, 10, 3679. [CrossRef]

19. MacLeod, M.; Eory, V.; Wint, W.; Shaw, A.; Gerber, P.; Cecchi, G.; Mattioli, R.; Sykes, A.; Robinson, T. Assessing the Greenhouse Gas Mitigation Effect of Removing Bovine Trypanosomiasis in Eastern Africa. Sustainability 2018, 10, 1633. [CrossRef]

20. Schmithausen, R.; Schulze-Geisthoevel, S.; Heinemann, C.; Bierbaum, G.; Exner, M.; Petersen, B.; Steinhoff-Wagner, J. Reservoirs and Transmission Pathways of Resistant Indicator Bacteria in the Biotope Pig Stable and along the Food Chain: A Review from a One Health Perspective. Sustainability 2018, 10, 3967. [CrossRef]

21. Baldi, M.; Collivignarelli, M.; Abbà, A.; Benigna, I. The Valorization of Ammonia in Manure Digestate by Means of Alternative Stripping Reactors. Sustainability 2018, 10, 3073. [CrossRef]

22. Mackenzie, S.G.; Leinonen, I.; Kyriazakis, I. The need for co-product allocation in the Life Cycle Assessment of agricultural systems-Is “biophysical” allocation progress? Int. J. Life Cycle Assess. 2017, 22, 128-137. [CrossRef]

(C) 2019 by the author. Licensee MDPI, Basel, Switzerland. This article is an open access article distributed under the terms and conditions of the Creative Commons Attribution (CC BY) license (http:/ / creativecommons.org/licenses/by/4.0/). 